\title{
Peningkatan Hasil Belajar Tematik Tema Pahlawanku Subtema Perjuangan Para Pahlawan dengan Metode Think Pair Share pada Siswa Kelas IV SD Negeri 3 Widoro Kecamatan Gandusari Semester 2 Tahun Pelajaran 2017/2018
}

\author{
Hadi Utomo \\ Sekolah Dasar Negeri 3 Widoro, Trenggalek \\ Email: hadiutomo058@gmail.com
}

\begin{abstract}
Abstrak: Penggunaan model dalam pembelajaran harus dilakukan dengan selektif, penggunaan model yang tidak tepat dapat menghambat tercapainya kemampuan belajar yang diharapkan dan rendahnya prestasi belajar siswa dalam pembelajaran tematik. Ini terjadi dkarena dalam proses belajar mengajar, siswa tidak aktif atau kurang dilibatkan dalam situasi optimal untuk belajar, pembelajaran cenderung berpusat pada guru, dan klasikal. Rumusan masalah dalam penelitian ini adalah Peningkatan Hasil Belajar Tematik Tema Pahlawanku Subtema Perjuangan para Pahlawan dengan Metode Think Pair Share pada Siswa Kelas IV SD Negeri 3 Widoro Kecamatan Gandusari Semester 2 Tahun Pelajaran 2017/2018 dan tujuan dari penelitian ini untuk mengetahui gambaran objektif tentang Peningkatan Hasil

Tersedia Online di

http://journal.unublitar.ac.id/pendidi

kan/index.php/Riset Konseptual

\begin{tabular}{l}
\hline Sejarah Artikel \\
\hline Diterima pada $: 21-10-2019$ \\
Disetujui pada : 23-10-2019 \\
Dipublikasikan pada : 31-10-2019 \\
\hline
\end{tabular}

Kata Kunci:

Hasil Belajar, Tematik, Think Pair Share

DOI:

http://doi.org/10.28926/riset_konseptual.v3i 4.155 Belajar. Penelitian ini terdiri dari dua siklus pembelajaran, yang masing-masing siklusnya terdiri dari perencanaan, pelaksanaan observasi dan refleksi. Subyek penelitian ini adalah seluruh siswa kelas IV SDN 3 Widoro Kecamatan Gandusari. Berdasarkan hasil penelitian yang dilakukan, pada siklus pertama siswa merasa kaku karena mereka belum terbiasa dengan metode pembelajaran ini dan hasil tes menunjukan nilai yang rendah. Ini dapat dilihat pada nilai tes siswa pra siklus yakni masih 4 siswa (50\%) dan meningkat pada siklus pertama 5 $(62,50 \%)$ siswa tuntas belajarnya dan rata-rata hasil belajar siswa meningkat dari siklus awal 66,25 menjadi 70,00 pada siklus pertama. Sedangkan pada siklus kedua siswa sudah mampu beradaptasi dengan metode Think Pair Share. Dan hasil tes belajar pun meningkat. Pada siklus ke dua sebanyak 8 siswa (100\%) tuntas belajarnya, dengan nilai rata-rata kelas sebesar 82,50.
\end{abstract}

\section{PENDAHULUAN}

Pembelajaran adalah sebagai pedoman bagi pengajar dan para guru dalam melaksanakan pembelajaran. Hal ini menunjukan bahwa setiap model yang akan digunakan dapat berpengaruh dalam pembelajaran serta harus mengetahui dalam menentukan model yang akan dilakukan dalam pembelajaran menentukan perangkat yang dipakai dalam pembelajaran tersebut. Pembelajaran kurikulum 2013 Sekolah Dasar menggunakan pendekatan scientific atau pendekatan ilmiah diatur didalam Permendikbud 103/2014 (Proses scientific).

Berdasarkan hal di atas pada subtema perjuangan para pahlawan maka hasil belajar peserta didik dapat di tunjukan dengan kerjasama peserta didik yang mewakilinya. Pembelajaran yang akan di kembangkan dalam penelitian ini adalah tentang tema Pahlawanku subtema perjuangan para pahlawan di kelas IV SDN 3 Widoro Kecamtan Gandusari. 
Berdasarkan hasil observasi di lapangan yakni pada dikelas IV Sekolah Dasar Negeri 3 Widoro Kecamtan Gandusari dalam menggunakan pembelajaran tematik di kelas 1 dan 4 kurangnya keaktifan siswa saat mengikuti kegiatan belajar mengajar, hal ini dikarekanan kurangnya pemahaman guru terhadap konsep pembelajaran tematik dan kurangnya kreativitas guru dalam mengemas model pembelajaran, terbukti hasil belajar siswa yang diperoleh sesuai KKM hanya $40 \%$ dan yang belum tuntas sesuai KKM 60\% dengan KKM yang telah ditentukan yaitu 70 Proses belajar mengajar masih berpusat pada guru, kegiatan Pembelajaran masih dilakukan secara konvensional, dengan guru lebih banyak menerangkan materi sedangkan siswa hanya mendengar saja. Sehingga siswa belum mampu mengembangkan bakat, kemampuan dan kreatifitasnya.

Menyikapi hal diatas, alternative pemecahan masalah yang dapat digunakana adalah dengan menerapkan metode Think Pair Share sebagai upaya untuk meningkatkan hasil belajar siswa. Proses pembelajaran harus dipandang sebagai rangsangan yang dapat menggugah semangat siswa untuk melakukan kegiatan pembelajaran. Peranan guru lebih banyak sebagai sahabat, pembimbing atau pemimpin belajar dan fasilitator belajar. Sehingga, siswa lebih banyak melakukan kegiatan sendiri atau dalam bentuk kelompok memecahkan permasalahan 1 dengan bimbingan guru.

Berdasarkan uraian diatas, maka peneliti tertarik untuk mengkaji lebih luas permasalahan, yaitu dengan penelitian yang berjudul "Peningkatan Hasil Belajar Tematik Tema Pahlawanku Subtema Perjuangan para Pahlawan dengan Metode Think Pair Share pada Siswa Kelas IV SD Negeri 3 Widoro Kecamatan Gandusari Semester 2 Tahun Pelajaran 2017/2018"

\section{HASIL dan PEMBAHASAN}

Penelitian ini adalah penelitian tindakan kelas (classroom action research) kolaborasi. Penelitian dilakukan dengan cara kolaboratif yaitu peneliti bekerja sama dengan teman sejawat. Peneliti sekaligus sebagai guru kelas yang melakukan pembelajaran sedangkan teman sejawat menjadi kolaboratornya. Pada penelitian kolaboratif, orang yang akan melakukan tindakan harus terlibat dalam proses penelitian dari awal. Penelitian ini akan menciptakan kerjasama antara peneliti dengan kolaboratornya. Peneliti sekaligus sebagai guru yang melaksanakan proses pembelajaran, maka sejak awal terlibat langsung dalam merencanakan penelitian. Peneliti memantau, mencatat, dan mengumpulkan data dibantu oleh observer, lalu menganalisa data serta berakhir dengan melaporkan hasil penelitiannya. Sehingga penelitian ini akan menciptakan kolaborasi atau partisipasi antara peneliti dengan observer.

Penelitian ini menggunakan model Kemmis dan Mc Taggart. Tiap- tiap siklus kegiatan terdiri atas empat sub kegiatan, yakni perencanaan (plan), pelaksanaan tindakan (action), observasi (observation), dan refleksi (reflection). Menurut Kemmis dan Mc Taggart, komponen acting (tindakan) dengan observing (pengamatan) dijadikan sebagai satu kesatuan karena kedua kegiatan harus dilakukan dalam satu kesatuan waktu, begitu berlangsungnya suatu tindakan, begitu pula observasi harus dilakukan. 


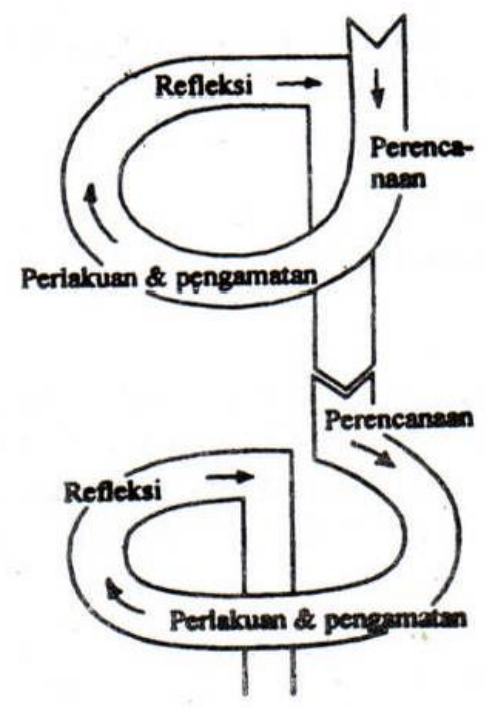

Gambar 1 Siklus Tindakan

(Kemmis dan Mc Taggart dalam Suharsimi, 2006:93)

\section{Tahap perencanaan (planning)}

Merupakan tahap penjelasan tentang apa, mengapa, kapan, dimana, oleh siapa dan bagaimana tindakan tersebut dilakukan. Peneliti juga menentukan fokus peristiwa yang perlu mendapatkan perhatian khusus untuk diamati, kemudian peneliti membuat sebuah instrumen pengamatan untuk membantu peneliti merekam fakta yang terjadi selama tindakan berlangsung.

2. Tahap pelaksanaan tindakan (acting)

Merupakan tahap implementasi atau tahap penerapan isi rancangan yaitu melakukan tindakan di kelas. Hal yang perlu diingat bahwa dalam tahap pelaksanaan ini, pelaksanaan harus ingat dan berusaha mentaati apa yang sudah dirumuskan dalam rancangan seperti berikut :

1. Kondisi Awal

Kegiatan pembelajaran untuk mata pelajaran tematik tema pahlawanku subtema perjuangan para pahlawan di kelas IV SDN 3 Widoro Kecamatan Gandusari. Kegiatan pembelajaran diawali dengan mengkondisikan siswa untuk siap belajar. Pada saat membuka pelajaran guru mengadakan tanya jawab tentang pelajaran yang telah dipelajari sebelumnya, kemudian mencoba menghubungkan dengan materi yang akan dipelajari. Guru menugaskan siswa untuk membaca dan mencatat materi yang baru di buku tulis. Di sini mulai terlihat aktivitas siswa yang semula tertarik menjadi menurun. Pada awal guru membuka pelajaran siswa tampak tertarik mengikuti kegiatan pembelajaran, namun ketertarikan siswa berkurang ketika guru menugaskan untuk membaca dan mencatat materi pelajaran, kemudian mendengarkan kembali penjelasan materi dari guru, dan hanya beberapa siswa yang tampak antusias untuk menjawab pertanyaan yang diajukan oleh guru.

Dalam awal pertemuan guru cenderung mengemas proses pembelajaran dalam bentuk verbalistis. Pengemasan ini tidak hanya mengakibatkan belajar tidak menarik melainkan membatasi aktivitas siswa. Guru jarang menggunakan alat peraga atau media pelajaran sains dan jarang pula melakukan percobaan. Kegiatan kelompokpun jarang dilaksanakan dan secara otomatis tidak ada diskusi kelas.Siswa tidak aktif karena guru terlalu mendominasi kegiatan pembelajaran.

Secara rinci temuan hasil penelitian awal pada observasi di kelas kelas IV SDN 3 Widoro Kecamatan Gandusari adalah bahwa setiap siswa 
kurang berkonsentrasi dalam mengikuti proses pembelajaran, dan masih ada beberapa siswa yang kurang memperhatikan ketika guru menyampaikan materi pelajaran. Siswa yang kurang tertarik itu ditujukan dengan bermainmain dengan sesuatu, mengobrol dengan teman sebangku dan tidak memperhatikan ketika guru menjelaskan, sehingga pemahaman siswa terhadap materi pelajaran sangatlah kurang. Hasil evaluasi siswa berupa nilai Tes yang dilaksanakan pada kegiatan awal ditunjukkan pada tabel di bawah ini.

Tabel 4.1 Rekapitulasi Nilai Tes Pembelajaran pada Kondisi Awal

\begin{tabular}{|c|c|c|c|c|}
\hline Nilai & Frekuensi & N×F & Presentase & Ketuntasan \\
\hline 100 & 0 & 0 & $0,00 \%$ & Tuntas \\
\hline 90 & 0 & 0 & $0,00 \%$ & Tuntas \\
\hline 80 & 3 & 240 & $37,50 \%$ & Tuntas \\
\hline 70 & 1 & 70 & $12,50 \%$ & Tuntas \\
\hline 60 & 3 & 180 & $37,50 \%$ & $\begin{array}{c}\text { Tidak } \\
\text { Tuntas }\end{array}$ \\
\hline 50 & 0 & 0 & $0,00 \%$ & $\begin{array}{c}\text { Tidak } \\
\text { Tuntas }\end{array}$ \\
\hline$<50$ & 1 & 40 & $12,50 \%$ & $\begin{array}{c}\text { Tidak } \\
\text { Tuntas }\end{array}$ \\
\hline $\begin{array}{l}\text { Ketuntsan } \\
\text { Klasikal }\end{array}$ & 8 & 530 & $100,00 \%$ & - \\
\hline Rata-rata & 4 & - & $50,00 \%$ & - \\
\hline
\end{tabular}

Oleh karena itu, melalui pelaksanaan penelitian tindakan kelas ini, peneliti melakukan sebuah inovasi dalam pembelajaran tematik tema pahlawanku subtema perjuangan para pahlawan dengan menggunakan metode Think pair share. Metode Think pair share sangat tepat jika diterapkan dalam proses pembelajaran karena dengan penerapan metode ini pembelajaran diharapkan dapat tumbuh berbagai kegiatan belajar siswa sehubungan dengan kegiatan belajar siswa. Dengan kata lain terciptalah interaksi edukatif. Dalam interaksi ini guru berperan sebagai penggerak atau pembimbing, sedangkan siswa berperan sebagai penerima atau yang dibimbing itu siswa akan merasa nyaman.

\section{Siklus I}

Setelah dilaksanakan perbaikan dengan metode Think Pair Share, hasil yang diharapkan dapat tercapai secara maksimal. Hal tersebut sebagaimana diuraikan pada penjelasan di bawah ini :

\section{a. Perencanaan}

Pada tahap perencanaan pada siklus I ditulis dalam bentuk RPP yang terdiri dari pendahuluan, kegiatan inti dan penutup yang disesuaikan dengan fase-fase metode Think Pair Share. (RPP selengkapnya terlampir) Perbedaan rancangan pembelajaran dengan menggunakan metode think pair share dari rancangan pembelajaran yang dibuat pada umumnya adalah pada kegiatan pembelajarannya lebih menekankan pada pemberian keleluasaan pada siswa untuk membangun pengetahuan yang telah mereka miliki sebelumnya, yang kemudian dengan temannya maupun dengan pelaksanaan diskusi kelompok maupun kelas, sehingga pembelajaran akan menjadi lebih 
bermakna bagi siswa sehingga hasil yang diharapkan dapat tercapai sesuai dengan tujuan pelaksanaan kegiatan pembelajaran.

\section{Pertemuan I}

$$
\text { b. Pelaksanaan Tindakan }
$$

Pelaksanaan pembelajaran menggunakan metode think pair share pada pembelajaran tematik tema pahlawanku subtema perjuangan para pahlawan dilaksanakan pada hari senin, 29 Januari 2018 dan Langkahlangkah kegiatan adalah sebagai berikut :

Di awal kegiatan guru memberi salam dan berdoa sesuai dengan keyakinan masing-masing. Kemudian guru mengecek kesiapan murid dengan mengisi lembar kehadiran, memeriksa kerapian dan tempat duduk disesuaikan dengan kegiatan pembelajaran dan menginformasikan tema yang akan dibelajarkan yaitu tentang "Pahlawanku". Guru menyampaikan tahapan kegiatan diantaranya mengamati, menanya, mengeksplorasi, mengomunikasikan dan menyimpulkan

Pada kegiatan inti guru menjelaskan aturan main dan batasan waktu tiap kegiatan, memotivasi siswa untuk terlibat pada aktivitas pemecahan masalah. Guru menjelaskan kompetensi yang harus dicapai oleh siswa, Guru menggali pengetahuan awal siswa melalui kegiatan tanya jawab kelas Menolong orang lain dengan ikhlas, berani, dan gigih merupakan sikap yang dimiliki oleh para pahlawan. Untuk menghargai mereka, kamu bisa meneladani sikap.Siswa dikelompokkan dengan teman disampingnya (sebangkunya) (pairing) Guru memberikan tugas yang telah disiapkan pada LKS di mana siswa diberikan bacaaan tentang Raja Punawarman dan diminta menjawab beberapa pertanyaan tentang bacaan, Siswa berdikusi dengan pasangannya mengenai jawaban tugas yang telah dikerjakan dan satu pasang siswa dipanggil secara acak untuk berbagi pendapat kepada seluruh siswa dengan dipandu oleh guru (Sharing) dan pada tahap akhir guru memberikan penghargaan kepada siswa yang dinilai baik secara individu maupun kelompok

Di kegiatan penutup guru bersama dengan siswa membuat kesimpulan hasil belajar selama sehari dan bertanya jawab tentang materi yang telah dipelajari. Selain itu guru memberi kesempatan kepada siswa untuk menyampaikan pendapatnya tentang pembelajaran yang telah diikuti, kemudian melakukan penilaian hasil belajar dilanjutkan dengan mengajak semua siswa berdo'a menurut agama dan keyakinan masing-masing.

\section{Pertemuan II}

Pelaksanaan pembelajaran pada pertertemuan 2 dilaksanakan pada hari selasa tanggal 30 Januari 2018.

Sesuai dengan hari sebelumnya guru memberikan salam dan mengajak semua siswa berdo'a lalu mengecek persiapan, kerapian, posisi dan tempat duduk disesuaikan dengan kegiatan pembelajaran. mengingatkan kembali tentang tema yang sebelumnya di pelajari yaitu tentang "Pahlawanku".dilanjutkan dengan guru menyampaikan tahapan kegiatan yang meliputi kegiatan mengamati, menanya, mengeksplorasi, mengomunikasikan dan menyimpulkan.

Pada kegiatan inti guru kembali mengulang kegiatan pembelajaran pada peremuan pertama dengan melanjutkan materi kemudian guru menggali pengetahuan awal siswa melalui kegiatan tanya jawab kelas, Guru mengajukan pertanyaan atau isu yang berhubungan dengan tema kepahlawanan dan memberi gambaran tentang beberapa tokoh dan peninggalan kerajaan pada masa kerajaan Hindu, Buddha, dan Islam. Pada kegiatan ini, siswa memikirkan pertanyaan atau isu secara mandiri individual. Siswa tidak boleh berbicara dengan siswa lain pada tahap ini.(think) kemudian siswa dikelompokkan dengan teman disampingnya 
(sebangkunya) (pairing) dan guru memberikan tugas yang telah disiapkan pada LKS di mana siswa diberikan gambar tenta g beberapa tokoh dan peninggalan kerajaan pada masa kerajaan Hindu, Buddha, dan Islam selanjutnya siswa diminta mencari tahu sejarah kerajaan dan para tokoh serta peninggalan yang terdapat pada gambar kemudian siswa berdiskusi dengan pasangannya mengenai jawaban tugas yang telah dikerjakan dan satu pasang siswa dipanggil secara acak untuk berbagi pendapat kepada seluruh siswa dengan dipandu oleh guru (Sharing) selanjutnya guru memberikan penghargaan kepada siswa dinilai baik secara individu maupun kelompok, setelah kegiatan selasai siswa mengerjakan soal evaluasi siklus I

Di kegiatan penutup guru bersama dengan siswa membuat kesimpulan hasil belajar selama sehari dan bertanya jawab tentang materi yang telah dipelajari. Selain itu guru memberi kesempatan kepada siswa untuk menyampaikan pendapatnya tentang pembelajaran yang telah diikuti, kemudian melakukan penilaian hasil belajar dilanjutkan dengan mengajak semua siswa berdo'a menurut agama dan keyakinan masing-masing.

c. Pengamatan

Hasil pengamatan pertemuan pertama dan kedua belum memenuhi kriteria yang diinginkan. Hal ini dikarenakan berdasakan hasil pengematan di lapangan pada siklus I ini pembelajaran masih dirasa belum optimal, sebab siswa selama proses pembelajaran masih banyak yang kurang serius dan tidak memanfaatkan waktu yang diberikan untuk diskusi dengan banik. Siswa cenderung mempergunakan waktunya untuk mengobrol dan bernmain sementara yang melaksanakan diskusi hanya sebagian siswa saja.

\section{d. Refleksi}

hasil pekerjaaan siswa dengan hasil sebagaimana dijelaskan di bawah ini.

Tabel 4.2 Rekapitulasi Nilai Tes Pembelajaran pada Siklus I

\begin{tabular}{|c|c|c|c|c|}
\hline Nilai & Frekuensi & $\mathbf{N} \mathbf{F}$ & Presentase & Ketuntasan \\
\hline 100 & 0 & 0 & $0,00 \%$ & Tuntas \\
\hline 90 & 0 & 0 & $0,00 \%$ & Tuntas \\
\hline 80 & 3 & 240 & $37,50 \%$ & Tuntas \\
\hline 70 & 2 & 140 & $25,00 \%$ & Tuntas \\
\hline 60 & 3 & 180 & $37,50 \%$ & $\begin{array}{c}\text { Tidak } \\
\text { Tuntas }\end{array}$ \\
\hline 50 & 0 & 0 & $0,00 \%$ & $\begin{array}{c}\text { Tidak } \\
\text { Tuntas }\end{array}$ \\
\hline$<50$ & 0 & 0 & $0,00 \%$ & $\begin{array}{c}\text { Tidak } \\
\text { Tuntas }\end{array}$ \\
\hline $\begin{array}{l}\text { Jumlah } \\
\text { Ketuntasan }\end{array}$ & 8 & 560 & $100,00 \%$ & - \\
\hline Ratala-rata & 5 & - & $62,50 \%$ & - \\
\hline
\end{tabular}

Dari tabel di atas dapat dijelaskan bahwa siswa tuntas 5 siswa atau $62,50 \%$, dengan perolehan nilai rata-rata hasil belajar sebesar 70,00 , sehingga masih terdapat 3 siswa atau $37,50 \%$ yang dinyatakan belum tuntas.

Dari tabel 4.2 tentang Rekapitulasi Nilai Tes di atas dapat diterangkan bahwa setelah dilakukan perbaikan pembelajaran dengan menggunakan metode Think Pair Share, nilai rata-rata meningkat menjadi 70,00, dan jumlah siswa yang telah mencapai tingkat ketuntasan belajar 5 siswa $(62,50 \%)$. Melihat hasil di atas maka peneliti bersama-sama dengan 
observer sepakat untuk melaksanakan perbaikan pembelajaran pada siklus II, karena nilai rata-rata hasil belajar baru mencapai angka 70,00 yang berarti masih berada di bawah KKM sebesar 65,00 sesuai dengan kriteria keberhasilan yang telah ditetapkan dan tingkat ketuntasan belajar baru $62,50 \%$. Hal ini menunjukkan ketuntasan belajar belum mencapai $85 \%$ dari jumlah seluruh siswa sesuai dengan kriteria keberhasilan yang telah

\section{Siklus II} ditentukan

Dengan mempertimbangkan hasil refleksi pada siklus pertama, maka pada siklus kedua peneliti mencoba menyempurnakan pelaksanaan perbaikan pembelajaran. Setelah dilaksanakan perbaikan pembelajaran dengan menggunakan metode Think Pair Share, hasil yang diharapkan dapat tercapai secara maksimal. Hal tersebut sebagaimana diuraikan pada penjelasan di bawah ini :

\section{a. Perencanaan}

Pada tahap perencanaan, data yang diperoleh berupa: RPP yang mencakup komponen skenario pembelajaran yang akan diimplementasikan; seperangkat instrumen yang akan digunakan untuk pengumpulan data; dan data pendukung pembelajaran dan penambahan inovasi-inovasi baru seputar pelaksanaan pembelajaran dengan metode Think Pair Share

\section{b. Pelaksanaan Tindakan}

\section{Pertemuan I}

Pelaksanaan pembelajaraan pada pertemuan pertama siklus II dilaksanakan pada hari selasa tanggal 5 Februari 2018. Pada pertemuan pertama dimulai dengan kegiatan pendahuluan :

Pada kegiatan pendahuluan guru memberikan salam dan mengajak semua siswa berdo'a menurut agama dan keyakinan masing-masing dilanjutkan dengan guru mengecek kesiapan diri dengan mengisi lembar kehadiran dan memeriksa kerapihan pakaian, posisi dan tempat duduk disesuaikan dengan kegiatan pembelajaran dan menginformasikan tema yang akan dibelajarkan yaitu tentang "Pahlawanku". Guru menyampaikan tahapan kegiatan yang meliputi kegiatan mengamati, menanya, mengeksplorasi, mengomunikasikan dan menyimpulkan

Pada kegiatan inti guru menjelaskan aturan main dan batasan waktu tiap kegiatan, memotivasi siswa untuk terlibat pada aktivitas pemecahan masalah. Guru menjelaskan kompetensi yang harus dicapai oleh siswa, Guru menggali pengetahuan awal siswa melalui kegiatan tanya jawab kelas yakni pada pertemuan sebelumnya siswa telah mempelajari tentang raja Balaputradeqa dari kerajaan Sriwijaya, dan pada pertemuan ini siswa akan mempelajari tentang Raja Balaputradewa dari kerajaan Sriwijaya.. Guru mengajukan pertanyaan atau isu yang berhubungan dengan tema kepahlawanan dan memberi gambaran tentang Raja Balaputradewa yang merupakan raja kerajaan Sriwijaya. Pada kegiatan ini, siswa memikirkan pertanyaan atau isu secara mandiri individual. Siswa tidak boleh berbicara dengan siswa lain pada tahap ini.(think) Siswa dikelompokkan dengan teman disampingnya (sebangkunya) (pairing) Guru memberikan tugas yang telah disiapkan pada LKS di mana siswa diberikan bacaaan tentang Raja Punawarman dan diminta menjawab beberapa pertanyaan tentang bacaan, Siswa berdikusi dengan pasangannya mengenai jawaban tugas yang telah dikerjakan dan satu pasang siswa dipanggil secara acak untuk berbagi pendapat kepada seluruh siswa dengan dipandu oleh guru (Sharing) dan pada tahap akhir guru memberikan penghargaan kepada siswa yang dinilai baik secara individu maupun kelompok

Di kegiatan penutup guru bersama dengan siswa membuat kesimpulan hasil belajar selama sehari dan bertanya jawab tentang materi 
yang telah dipelajari. Selain itu guru memberi kesempatan kepada siswa untuk menyampaikan pendapatnya tentang pembelajaran yang telah diikuti, kemudian melakukan penilaian hasil belajar dilanjutkan dengan mengajak semua siswa berdo'a menurut agama dan keyakinan masing-masing.

\section{Pertemuan II}

Pada pertemuan kedua yang dilaksanakan pada hari selasa tanggal 6 Februari 2018 adapun langka langka sebagai berikut :

Pada kegiatan pendahuluan guru memberikan salam dan mengajak semua siswa berdo'a menurut agama dan keyakinan masing-masing. guru mengecek kesiapan diri dengan mengisi lembar kehadiran dan memeriksa kerapihan pakaian, posisi dan tempat duduk disesuaikan dengan kegiatan pembelajaran. mengingatkan kembali tentang tema yang seblumnya di pelajari yaitu tentang "Pahlawanku".dilanjutkan dengan guru menyampaikan tahapan kegiatan yang meliputi kegiatan mengamati, menanya, mengeksplorasi, mengomunikasikan dan menyimpulkan.

Pada kegiatan inti guru kembali mengulang kegiatan pembelajaran pada peremuan pertama dengan melanjutkan materi kemudian guru menggali pengetahuan awal siswa melalui kegiatan tanya jawab kelas, Guru mengajukan pertanyaan atau isu yang berhubungan dengan tema kepahlawanan dan memberi gambaran tentang sikap-sikap yang sesuai dengan sila keempat Pancasila. Pada kegiatan ini, siswa memikirkan pertanyaan atau isu secara mandiri individual. Siswa tidak boleh berbicara dengan siswa lain pada tahap ini.(think) kemudian siswa dikelompokkan dengan teman disampingnya (sebangkunya) (pairing) dan guru memberikan tugas yang telah disiapkan pada LKS di mana siswa diberikan gambar tenta g beberapa tokoh dan peninggalan kerajaan pada masa kerajaan Hindu, Buddha, dan Islam selanjutnya siswa diminta mencari tahu sejarah kerajaan dan para tokoh serta peninggalan yang terdapat pada gambar kemudian siswa berdiskusi dengan pasangannya mengenai jawaban tugas yang telah dikerjakan dan satu pasang siswa dipanggil secara acak untuk berbagi pendapat kepada seluruh siswa dengan dipandu oleh guru (Sharing) selanjutnya guru memberikan penghargaan kepada siswa dinilai baik secara individu maupun kelompok, setelah kegiatan selasai siswa mengerjakan soal evaluasi siklus II

Di kegiatan penutup guru bersama dengan siswa membuat kesimpulan hasil belajar selama sehari dan bertanya jawab tentang materi yang telah dipelajari. Selain itu guru memberi kesempatan kepada siswa untuk menyampaikan pendapatnya tentang pembelajaran yang telah diikuti, kemudian melakukan penilaian hasil belajar dilanjutkan dengan mengajak semua siswa berdo'a menurut agama dan keyakinan masing-masing.

c. Pengamatan

Dari hasil pelaksanaan siklus ke dua diketahui bahwa pelaksanaan pembelajaran siklus kedua kegiatan belajar siswa telah mengalami peningkatan yang berarti. Dengan pantauan guru siswa dapat memaksimalkan waktu yang ada untuk melaksanakan diskusi beik dengan kelompok ahli maupun kelompok asal. Siswa cenderung lebih antusias dan bersemangat karena metode think pair share memberikan nuansa baru dalam kegiatan belajar mengajar. Selain itu hasil belajar telah mencapai ketuntasan $100 \%$ atau 8 siswa, dengan perolehan nilai rata-rata hasil belajar sebesar 82,50

d. Refleksi bawah ini.

Data hasil pekerjaaan siswa dengan hasil sebagaimana dijelaskan di 
Tabel 4.3 Rekapitulasi Nilai Tes Pembelajaran pada Siklus II

\begin{tabular}{|c|c|c|c|c|}
\hline Nilai & Frekuensi & $\mathbf{N \times F}$ & Presentase & Ketuntasan \\
\hline 100 & 1 & 100 & $12,50 \%$ & Tuntas \\
\hline 90 & 2 & 180 & $25,00 \%$ & Tuntas \\
\hline 80 & 3 & 240 & $37,50 \%$ & Tuntas \\
\hline 70 & 2 & 140 & $25,00 \%$ & Tuntas \\
\hline 60 & 0 & 0 & $0,00 \%$ & Tidak Tuntas \\
\hline 50 & 0 & 0 & $0,00 \%$ & Tidak Tuntas \\
\hline$<50$ & 0 & 0 & $0,00 \%$ & Tidak Tuntas \\
\hline Jumlah & 8 & 660 & $100,00 \%$ & - \\
\hline $\begin{array}{l}\text { Ketuntsan } \\
\text { Klasikal }\end{array}$ & 8 & - & $100,00 \%$ & - \\
\hline \multicolumn{1}{|l|}{82,50} & \\
\hline
\end{tabular}

Dari tabel di atas dapat dimaknai bahwa siswa tuntas 8 siswa atau $100 \%$, dengan perolehan nilai rata-rata hasil belajar sebesar 82,50 , Melihat hasil di atas maka peneliti bersama-sama dengan observer menunjukkan sudah melebihi KKM minimal 65, dengan jumlah siswa yang telah tuntas belajarnya sebanyak 8 siswa atau $100 \%$. Hal ini menunjukkan bahwa ketuntasan belajar juga telah mencapai kriteria keberhasilan sebesar $85 \%$ sehingga proses perbaikan pembelajaran dinyatakan berhasil dan tuntas pada pelaksanaan pembelajaran pada siklus II

\section{B. Pembahasan}

1. Siklus I

Adapun penjelasan mengenai hasil pelaksanaan perbaikan pembelajaran pada siklus pertama adalah sebagai berikut :

Hasil belajar meningkat cukup baik, yaitu dari nilai rata-rata hasil belajar sebesar 70,00 pada sebelum perbaikan 66,25 pada siklus pertama, sedangkan tingkat ketuntasan belajar baru mencapai angka 4 siswa atau 50\%. Melihat hasil tersebut maka peneliti bersama-sama dengan observer sepakat untuk melaksanakan perbaikan pembelajaran pada siklus II, karena nilai rata-rata hasil belajar baru mencapai angka 66,25 yang berarti masih berada di bawah KKM sebesar 65,00 sesuai dengan kriteria keberhasilan yang telah ditetapkan dan tingkat ketuntasan belajar baru 50\%. Hal ini menunjukkan ketuntasan belajar belum mencapai $85 \%$ dari jumlah seluruh siswa sesuai dengan kriteria keberhasilan yang telah ditentukan

2. Siklus II

Siklus II peneliti menggunakan metode Think Pair share. Hasil perbaikan pembelajaran siklus II sudah mengalami kenaikan dibanding siklus I, Hasil belajar pada siklus II meningkat cukup baik, yaitu dari nilai rata-rata hasil belajar sebesar 70,00 pada siklus pertama, menjadi 82,50 pada siklus kedua, sedangkan tingkat ketuntasan belajar mencapai angka 8 siswa atau $100 \%$. Melihat hasil tersebut maka peneliti bersama-sama dengan observer menyimpulkan bahwa hasil tes hasil belajar menunjukkan sudah melebihi KKM minimal 65, dengan jumlah siswa yang telah tuntas belajarnya sebanyak 8 siswa atau $100 \%$. Hal ini menunjukkan bahwa ketuntasan belajar juga telah mencapai kriteria keberhasilan sebesar $85 \%$ sehingga proses perbaikan pembelajaran dinyatakan berhasil dan tuntas pada pelaksanaan pembelajaran pada siklus II

Dari analisa di atas dapat disimpulkan bahwa penggunaan metode think pair share menunjukkan peningkatan yang signifikan terhadap proses dan hasil pembelajaran. Penjelasan secara rinci dapat dilihat pada tabel di bawah ini : 


\section{Tabel $\quad 4.4$ Rekapitulasi Ketuntasan Belajar Siswa pada pada Sebelum Perbaikan, Siklus I dan Siklus II}

\begin{tabular}{|c|c|c|c|c|c|c|}
\hline \multirow[t]{2}{*}{ No } & \multirow[t]{2}{*}{ Pembelajaran } & \multicolumn{5}{|c|}{ Hasil Belajar Siswa } \\
\hline & & $\begin{array}{l}\text { Nilai } \\
\text { Rata2 }\end{array}$ & $\begin{array}{c}\text { Tunta } \\
\text { s }\end{array}$ & $\%$ & Belum & $\%$ \\
\hline 1. & $\begin{array}{l}\text { Sebelum } \\
\text { perbaikan }\end{array}$ & 66,25 & 4 & 50.00 & 4 & 50.00 \\
\hline 2. & Siklus I & 70.00 & 5 & 62.50 & 3 & 37.50 \\
\hline 3. & Siklus II & 82.50 & 8 & 100.00 & 0 & 0.00 \\
\hline
\end{tabular}
berikut :

Dari penjelasan pada tabel di atas, diperoleh keterangan sebagai

Pada sebelum perbaikan, angka ketuntasan sebesar $50,00 \%$ atau hanya 4 siswa dari 8 siswa.

Pada siklus I, angka ketuntasan belajar naik menjadi $62,50 \%$ atau 5 siswa dari 8 siswa.

3) Pada siklus II, angka ketuntasan belajar naik menjadi 100\% atau atau 8 siswa dari 8 siswa.

4) Pada sebelum perbaikan nilai rata-rata sebesar 66,25 meningkat menjadi 70,00 dan 82,50 pada siklus kedua.

Untuk lebih jelasnya tentang penjelasan peningkatan hasil belajar siswa dan nilai rata-rata hasil belajar secara klasikal pada sebelum perbaikan, siklus I dan siklus II dapat dilihat pada gambar diagram batang berikut ini :

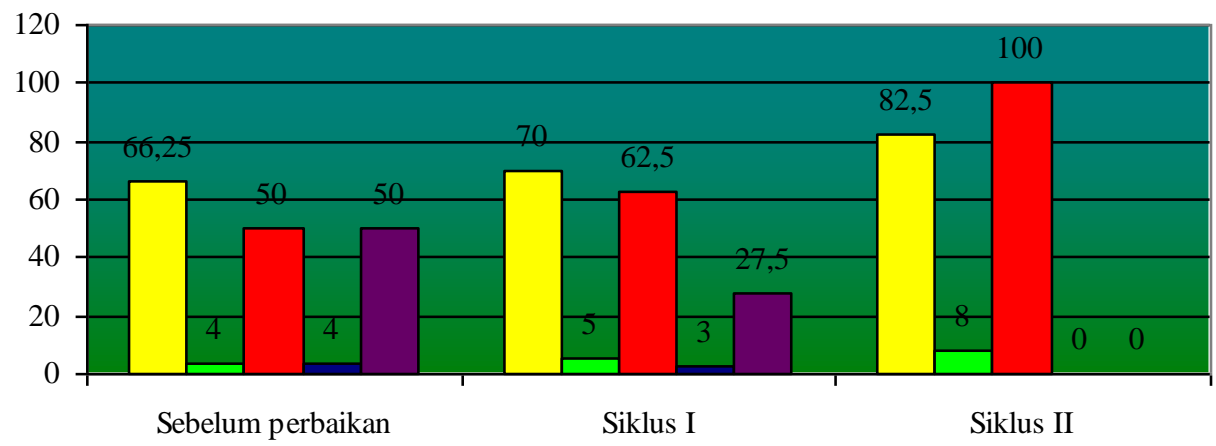

$\square$ Nilai $\square$ Tuntas $\square$ Persentase $\mathbf{\square}$ Belum Tuntas $\square$ Persentase

\section{Gambar 3 Diagram Batang Peningkatan Angka Nilai Rerata Hasil Belajar dan Ketuntasan Siswa pada Setiap Siklus Perbaikan Pembelajaran}

Dari penjelasan mengenai proses dan hasil proses perbaikan pembelajaran sebagaimana dijelaskan di atas, dapat disimpulkan bahwa hasil belajar siswa yang terjadi pada setiap siklus menunjukkan kenaikan yang signifikan. Hal tersebut didukung pula oleh kenaikan hasil belajar siswa dari rata-rata pada sebelum perbaikan hanya 66,25 , naik menjadi 70,00 pada siklus pertama, dan 82,50 pada siklus kedua, dengan tingkat ketuntasan belajar sebanyak 4 siswa (50\%) pada sebelum perbaikan, $62,50 \%$ atau 5 siswa pada siklus pertama, 8 siswa atau $100 \%$ pada siklus kedua, dan secara klasikal semua indikator dan kriteria keberhasilan proses perbaikan pembelajaran telah terpenuhi, sehingga dapat disimpulkan bahwa proses perbaikan pembelajaran dinyatakan berhasil dan tuntas pada siklus kedua. 


\section{KESIMPULAN}

Berdasarkan analisis data dan hasil termuan pada pelaksanaan penelitian tindakan kelas dengan menggunakan metode think pair share yang dilaksanakan dalam dua siklus, dapat dibuat kesimpulan sebagai berikut :

Penggunaan metode think pair share dapat meningkatkan hasil belajar Tematik Tema Pahlawanku Subtema Perjuangan para Pahlawan pada siswa kelas IV SD Negeri 3 Widoro Kecamatan Gandusari Tahun Pelajaran 2017/2018 terbukti mampu meningkatkan hasil belajar siswa, dari nilai rata-rata kelas terus mengalami peningkatan dari 66.25 pada studi awal menjadi 70,00 pada siklus pertama, meningkat menjadi 82,50 dan pada akhir siklus kedua, dengan tingkat ketuntasan belajar yang juga meningkat pada setiap siklusnya, yaitu 4 orang siswa $(50,00 \%)$ pada studi awal, menjadi $62,50 \%$ atau 5 siswa, meningkat lagi menjadi $82,50 \%$ atau 8 siswa pada akhir siklus kedua. Secara klasikal hasil proses pembelajaran pada telah memenuhi kriteria keberhasilan, sehingga dapat dinyatatakan selesai dan berhasil pada siklus kedua.

\section{DAFTAR RUJUKAN}

Achmad, Sugandi, dkk. (2006). Teori Pembelajaran. Semarang: UPT MKK. UNNES

Agus suprijono. (2010). Cooperative Learning. Yogyakarta. Pustaka Media.

Agus suprijono. (2010). Cooperative Learning. Yogyakarta. Pustaka Media.

Alma, B. (2009). Pemasaran Jasa Pendidikan. Bandung: CV. Alfabeta.

Ani., M. d. (2006). Psikologi Perkembangan. Ciputat: Quantum.

Anni, Catharina Tri, dkk. 2006. Psikologi Belajar. Semarang: Universitas. Negeri Semarang Press.

Arikunto, S., (2009). Prosedur Penelitian Suatu Pendekatan Praktik. Edisi Revisi 6. Jakarta : Rineka Cipta.

Arikunto, Suharsimi. (2005). ManajemenPenelitian. Jakarta: RinekaCipta.

Arikunto, Suharsimi. (2011). Prosedur Penelitian: Suatu Pendekatan Praktik. Edisi. Revisi VII. Jakarta: PT. Rineka Cipta.

B. Uno, Hamzah. (2008). Teori Motivasi dan Pengukurannya, Jakarta : Bumi. Aksara.

Darsono. (2000). Belajar dan Pembelajaran. Semarang : IKIP Press.

Gino. (1997). Psikologi Pengajaran. Yogyakarta : Media Abadi.

Hamalik, Umar. (1983). Metodologi Belajar dan Kesulitan-kesulitan Belajar. Jakarta: Bumi Aksara

Huda, Miftahul. (2011). Cooperative Learning. (Yogyakarta: Pustaka Belajar).

Jauhan,A. dan Elisah,T. (2011). Implementasi Pendidikan Karakter dalam Pembelajaran. Jakarta : Prestasi Pustaka

Kemendikbud. (2006). Permendikbud Nomor 22 Tahun 2006 Tentang Standar Isi. Jakarta: Kementerian Pendidikan dan Kebudayaan RI.

Made Wena. (2009). Strategi Pembelajaran Inovatif Kontemporer. Jakarta: Bumi. Aksara.

Moleong, Lexy. (2002). Metodologi Penelitian Kualitatif. Bandung: PT. remaja Rosdakarya

Nana Sudjana. (2002). Penilaian Hasil Proses Belajar Mengajar. Bandung: Remaja Rosdakarya.

Prawiradilaga, Dewi Salma dan Eveline Siregar. (2008). Prinsip Disain Pembelajaran. Jakarta: Kencana

Rusman. (2010). Model Model Pembelajaran. Bandung: Rajawali Pers,

Slavin, R. E. (2010). Cooperative Learning Teori, Riset dan Praktik. Bandung: Nusa Media.

Sudjana. (2006). Metode Statistik. Jakarta: Rineka Cipta.

Trianto. Mendesain Model Pembelajaran Inovatif-Progresif. Ed ke 4. (hal.41) Jakarta : Kencana.

Undang-Undang No. 20 tahun 2003 Tentang Sistem Pendidikan. Nasional. Jakarta 